\title{
On the Wind Energy Resource and Its Trend in the East China Sea
}

\author{
Adekunle Ayodotun Osinowo, Xiaopei Lin, Dongliang Zhao, and Kaiwen Zheng \\ College of Physical and Environmental Oceanography, Ocean University of China, Qingdao 266100, China \\ Correspondence should be addressed to Adekunle Ayodotun Osinowo; voxfox99@yahoo.com
}

Received 28 May 2016; Revised 18 November 2016; Accepted 13 December 2016; Published 20 February 2017

Academic Editor: Shuhui Li

Copyright ( 2017 Adekunle Ayodotun Osinowo et al. This is an open access article distributed under the Creative Commons Attribution License, which permits unrestricted use, distribution, and reproduction in any medium, provided the original work is properly cited.

\begin{abstract}
This study utilizes a 30-year (1980-2009) $10 \mathrm{~m}$ wind field dataset obtained from the European Center for Medium Range Weather Forecast to investigate the wind energy potential in the East China Sea (ECS) by using Weibull shape and scale parameters. The region generally showed good wind characteristics. The calculated annual mean of the wind power resource revealed the potential of the region for large-scale grid-connected wind turbine applications. Furthermore, the spatiotemporal variations showed strong trends in wind power in regions surrounding Taiwan Island. These regions were evaluated with high wind potential and were rated as excellent locations for installation of large wind turbines for electrical energy generation. Nonsignificant and negative trends dominated the ECS and the rest of the regions; therefore, these locations were found to be suitable for small wind applications. The wind power density exhibited an insignificant trend in the ECS throughout the study period. The trend was strongest during spring and weakest during autumn.
\end{abstract}

\section{Introduction}

Offshore wind power refers to the construction of wind farms in large bodies of water to generate electricity. These installations can utilize frequent and powerful available wind. In addition, offshore wind power elicits less aesthetic effect on the landscape than on land-based projects. Offshore wind energy utilizes wind power through turbines located in coastal and ocean waters to produce electricity, which is transmitted by cables to the mainland grid. As a sustainable and clean source of renewable energy, wind power exhibits significant potential to improve Massachusetts efforts in diversifying energy sources and reducing greenhouse gas reduction. Offshore wind is more productive than onshore (or land-based) wind because the former exhibits higher and more consistent wind speeds over the ocean. However, construction and operation of offshore wind farms, where groups of turbines are located together, remain challenging. Optimization of the technology to regional site conditions leads to development in the local supply chain and decline in operating costs; thus, wind power is predicted to become an important source of electricity for many states in the Northeast and Mid-Atlantic.

Offshore wind can generate large amounts of energy from few turbines because of its high wind resource capacity. Offshore wind is also suitable for large-scale development near major demand centers and does not require long transmission lines. Although offshore wind is the most popular in the wind sector, this energy source represents only $3 \%$ of the global installed capacity. In 2015, 3,398 MW of new offshore capacity was added, which brings the total capacity to 12,107 MW.

Previous studies on the onshore wind and offshore gas industry confirmed the success of offshore wind power technology $[1,2]$. As a result, offshore wind power of nearly $40 \mathrm{GW}$ (from $3 \mathrm{GW}$ reported in 2010) will be established in Europe until 2020 [3]

Several methods can be used to evaluate wind resources at a specific site; these methods include interview of people with local knowledge to identify regions with high and/or low wind speed, measurements only, measurement-correlation-prediction method, use of global databases, wind atlas 
methodology, site data-based modeling, and mesoscale and microscale modeling $[4,5]$. Offshore wind power mapping has improved using remote sensing data [6]. Europe is a global leader in the wind industry, and the pioneer offshore wind farm was mounted in Denmark in 1991 [7].

Wind energy in good onshore locations is utilized for economic profit and competes with other power-generating sources. Offshore wind power exhibits higher wind speed than onshore wind speed [8]. Based on the European Wind Energy Association [9], the annual addition in the installed capacity of offshore global wind power exhibits a rising trend yearly from 2001 to 2010, resulting in rapid increase in the cumulative wind power installed capacity. A previous study used both in situ and satellite data and both theoretical and practical methods for assessment of wind turbine performance to determine the offshore wind power potential of the southern coast of Brazil [10]. This study also used bathymetry and analyzed the characteristics of the current wind-electric technology to construct the maps of wind speed, wind power density, and practical turbine output in megawatts. The results indicated that the most favorable conditions are along the coast between $281^{\circ}$ and $331^{\circ} \mathrm{S}$ in the shallow water of South Brazil; the estimated average electrical production in one coastal region (102 GW) is equivalent to the electricity demand of the whole country. Moreover, another study used the meteorological data of the National Buoy Data Center to estimate the hourly power output from offshore wind turbine at the sites of the buoys; the experiment was conducted on the electric power generation of colocated offshore wind turbines and wave energy converters along the California coast [11]. The results showed that the variations in the offshore wind farm capacity factor ranged from $30 \%$ to $50 \%$. Reference [12] used a 2-year mean wind speed at $10 \mathrm{~m}$ to evaluate the offshore wind power potential of Zakynthos and Pylos in the Ionian Sea. The researchers reported annual average wind speeds of 5.7 and $5.8 \mathrm{~m} / \mathrm{s}$ at these locations. Reference [13] used wind speed data over 10 buoy stations in the Aegean and Ionian Seas to preliminary assess and calculate the magnitude of wind power density at $50 \mathrm{~m}$ above the water level. Mykonos was categorized as an excellent windy location of class 7 winds with wind power density of $971 \mathrm{~W} / \mathrm{m}^{2}$. Petrokaravo and Kalamata with wind power densities of 368 and $206 \mathrm{~W} / \mathrm{m}^{2}$ were rated as fair and marginal locations with wind power classes of 3 and 2, respectively. The rest of the locations were classified as good and outstanding. SeaWind I $(30 \mathrm{~km}$ horizontal resolution for 60 years) and SeaWind II ( $15 \mathrm{~km}$ horizontal resolution for 20 years) were also used to characterize offshore wind fields and evaluate the wind energy potential in the Mediterranean Sea [14]. This study reported interesting local characteristics, such as regions of more than $350 \mathrm{~W} / \mathrm{m}^{2}$ of raw wind power at a height of $10 \mathrm{~m}$, coastal regions with less than 6000 hours of wind speed between 2.5 and $25 \mathrm{~m} / \mathrm{s}$, and Mediterranean offshore regions with a 50 -year return period and wind speed higher than $25 \mathrm{~m} / \mathrm{s}$. Moreover, wind energy potential in the coastal environment of the Black and Caspian seas was investigated using 10 -year $10 \mathrm{~m}$ wind speed data from the US National Centers for Environmental Prediction [15]. The western side of the Black Sea has high wind power potential particularly around the Crimean peninsula, whereas the northeastern sector has high energy potential in the Caspian Sea. Reference [16] evaluated offshore wind resources in the Korean Peninsula by using the long-term QuikSCAT data. Furthermore, [17, 18] developed a high precision numerical wind map for the coastal regions of the Korean Peninsula to systematically investigate the potential of offshore wind power.

Wind energy generation in the ECS relies solely on wind resource availability that varies with location. A thorough assessment of wind energy potential in the ECS must be conducted before building a wind farm. A detailed assessment in promising locations should be subsequently performed [19]. Limited studies assessed wind energy potential in the ECS. The current study aims to estimate the wind energy potential of the ECS by using a 30-year, 6-hour, $10 \mathrm{~m}$ wind speed of ECMWF computed by the WAVEWATCH III (WW3) model. Results were compared with similar previous studies performed in other oceanic regions such as the offshore locations of Mediterranean Sea, Aegean with Ionian Seas, and Black with Caspian Seas. Spatiotemporal variations in wind power density found in the ECS were also investigated.

The paper is organized as follows. Section 2 provides information on the model, the wind field data, and the thorough validation of ECMWF wind speed with wind speed obtained from buoys by using statistical tests.

Section 3 presents the methods used in wind energy assessment and a detailed discussion on the obtained results. Finally, the conclusions of this study are provided in Section 4.

\section{Model Configurations}

The recent WAVEWATCH III version 4.18 was used in this study. New parameters related to the source terms were included in this official version. The parameters for spectral dissipation of wind-generated waves, wave breaking, swell dissipation, and many properties were significantly improved. The water depth field with a resolution of $0.1^{\circ} \times 0.1^{\circ}$ was processed by the Gridgen 3.0 packet according to the ETOPO 1 data of National Geophysical Data Center. Source terms for energy spectra in the model were set to default. The model integrated the spectrum to a cut-off frequency, and a parametric tail was applied above this frequency. The other option settings were 36 directions and 24 discrete wavenumbers $(0.0412-0.4060 \mathrm{~Hz}, 2.4-24.7 \mathrm{~s})$. Based on the ERAInterim reanalysis wind field datasets, the model output is a two-dimensional (2D) wave energy spectrum obtained at each grid point from 1 January 1980 to 31 December 2009 at a 6-hour interval. The model includes $10 \mathrm{~m}$ wind speed and ocean wave parameters, such as significant wave height, wave direction, and peak wave period. Reanalysis is a combination of the model information and observation of different kinds to produce a consistent and reliable global estimate of various atmospheric, wave, and oceanographic parameters. ERAInterim utilized the altimeter wave height observations to constrain the wave spectrum predicted by the WAM wave model. However, some physics and numerical differences were observed between the WW3 and WAM models. 


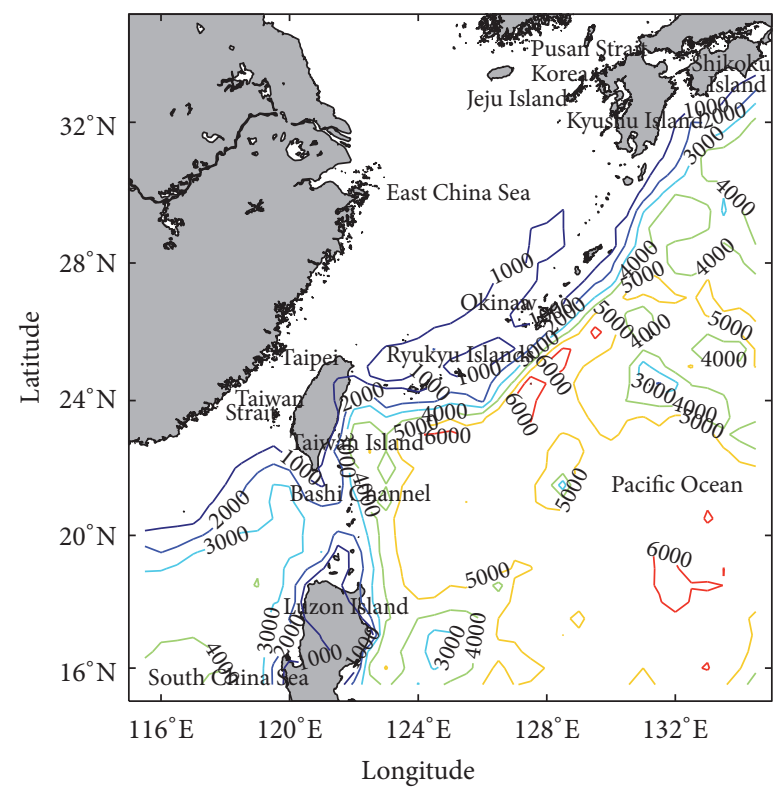

FIGURE 1: Topography of the East China Sea and surrounding waters.

2.1. Data and Methodology. As long-term ECMWF, ERAInterim wind field dataset within the space scope of $15^{\circ}-47^{\circ} \mathrm{N}$ and $105^{\circ}-135^{\circ} \mathrm{E}$ and a spatial resolution of $0.125^{\circ}$ by $0.125^{\circ}$ was used to force the WW3 model. The 6-hour, zonal (u10), and meridional $(v 10)$ wind field data were spanned from 00.00 (January 1, 1980) to 18.00 (December 31, 2009). The model output $10 \mathrm{~m}$ wind speed at a spatial resolution of $0.1^{\circ}$ by $0.1^{\circ}$ was computed as the square root of sum of the squares of the $u$ and $v$ wind components.

For the removal of boundary effects and the precise computation of wind speed, the computation region was set as $15^{\circ}-47^{\circ} \mathrm{N}, 105^{\circ}-13^{\circ} \mathrm{E}$, whereas the $10 \mathrm{~m}$ wind field was extracted within the study area of $15^{\circ}-35^{\circ} \mathrm{N}, 115^{\circ}-135^{\circ} \mathrm{E}$, which includes the East China Sea and its surrounding regions as shown in Figure 1. The calculating time is from 1980-01-01 00.00 to $2009-12-31$ 18.00, with a calculation time step of 360 , 180,180 , and $60 \mathrm{~s}$, and a 6-hour output data.

2.2. Data Validation. Figure 2 shows the comparisons of wind speed acquired from observations from eight China buoy stations and from computation with the model over the buoy coordinates. The result shows a good agreement between the buoy and ECMWF wind speeds on the curve trends.

The accuracy of the wind speed computed by the model was evaluated through a conventional statistical analysis with the following equation [20]:

$$
\begin{aligned}
c c & =\frac{\sum_{i-1}^{n}\left(x_{i}-\bar{x}\right)\left(y_{i}-\bar{y}\right)}{\sqrt{\sum_{i-1}^{n}\left(x_{i}-\bar{x}\right)^{2} \sum_{i-1}^{n}\left(y_{i}-\bar{y}\right)^{2}}}, \\
\text { Bias } & =\bar{y}-\bar{x}, \\
\text { RMSE } & =\sqrt{\frac{1}{N} \sum_{i-1}^{n}\left(y_{i}-x_{i}\right)^{2}},
\end{aligned}
$$

TABLE 1: Statistical errors of observed (buoy)/satellite (ECMWF) $10 \mathrm{~m}$ wind speed data comparison for the period of 2015 in the ECS: correlation coefficient $(\mathrm{CC})$, bias $(\mathrm{m} / \mathrm{s})$, and root mean square error (RMSE).

\begin{tabular}{lccc}
\hline Buoy identifier & CC & Bias $(\mathrm{m} / \mathrm{s})$ & RMSE $(\mathrm{m} / \mathrm{s})$ \\
\hline CB-1001 & 0.873 & -0.259 & 1.599 \\
CB-1002 & 0.888 & -0.425 & 1.531 \\
CB-1004 & 0.834 & -0.185 & 1.863 \\
CB-1007 & 0.853 & -0.483 & 1.821 \\
CB-1008 & 0.882 & -0.105 & 1.406 \\
CB-1009 & 0.839 & -0.323 & 1.928 \\
CB-1010 & 0.837 & -0.181 & 1.814 \\
CB-1012 & 0.904 & -0.831 & 1.698 \\
\hline
\end{tabular}

where $x_{i}$ represents the buoy data, $y_{i}$ represents the model data, $x$ and $y$ are the mean values of buoy and model data, and $N$ is the total number of observations.

As shown in Table 1, the computed and observed wind speed values were highly correlated with CC larger than 0.8 for eight cases and significant at $99 \%$ level. The calculated negative biases, which ranged from $-0.483 \mathrm{~m} / \mathrm{s}$ to $-0.105 \mathrm{~m} / \mathrm{s}$ and with low taking value, revealed that the model data are slightly higher than the buoy data. The errors of model data, which ranged between 1.406 and $1.928 \mathrm{~m} / \mathrm{s}$, remained low when analyzed by RMSE.

In summary, the ECMWF wind can be used to analyze the wind energy potential of the ECS.

\section{Analysis Methods}

3.1. Computation of Wind Energy. For a long time, statistical models such Rayleigh, Weibull, log-normal, and normal were used in wind data analysis [22]. Among the statistical models, the two-parameter Weibull probability distribution function is generally acceptable for wind data assessment because of its compatibility with experimental data [23]. The model is an overall gamma function that computes the wind power density and describes the wind speed frequency distribution [24]. Therefore, this study employed the two-parameter Weibull distribution function to compute wind power density. [24] as

The Weibull probability density function is expressed in

$$
f(v)=\frac{k}{c}\left(\frac{v}{c}\right)^{k-1} \exp \left[-\left(\frac{v}{c}\right)^{k}\right]
$$

The corresponding cumulative density function is expressed in [24] as

$$
F(v)=1-\exp \left[-\left(\frac{v}{c}\right)^{k}\right],
$$

where $k$ and $c$ are the shape and scale parameters, respectively; $v$ is the wind speed; $k$ (dimensionless) represents the variation in the average wind speed in a given sample; and $c(\mathrm{~m} / \mathrm{s})$ indicates the wind potential at a location that 

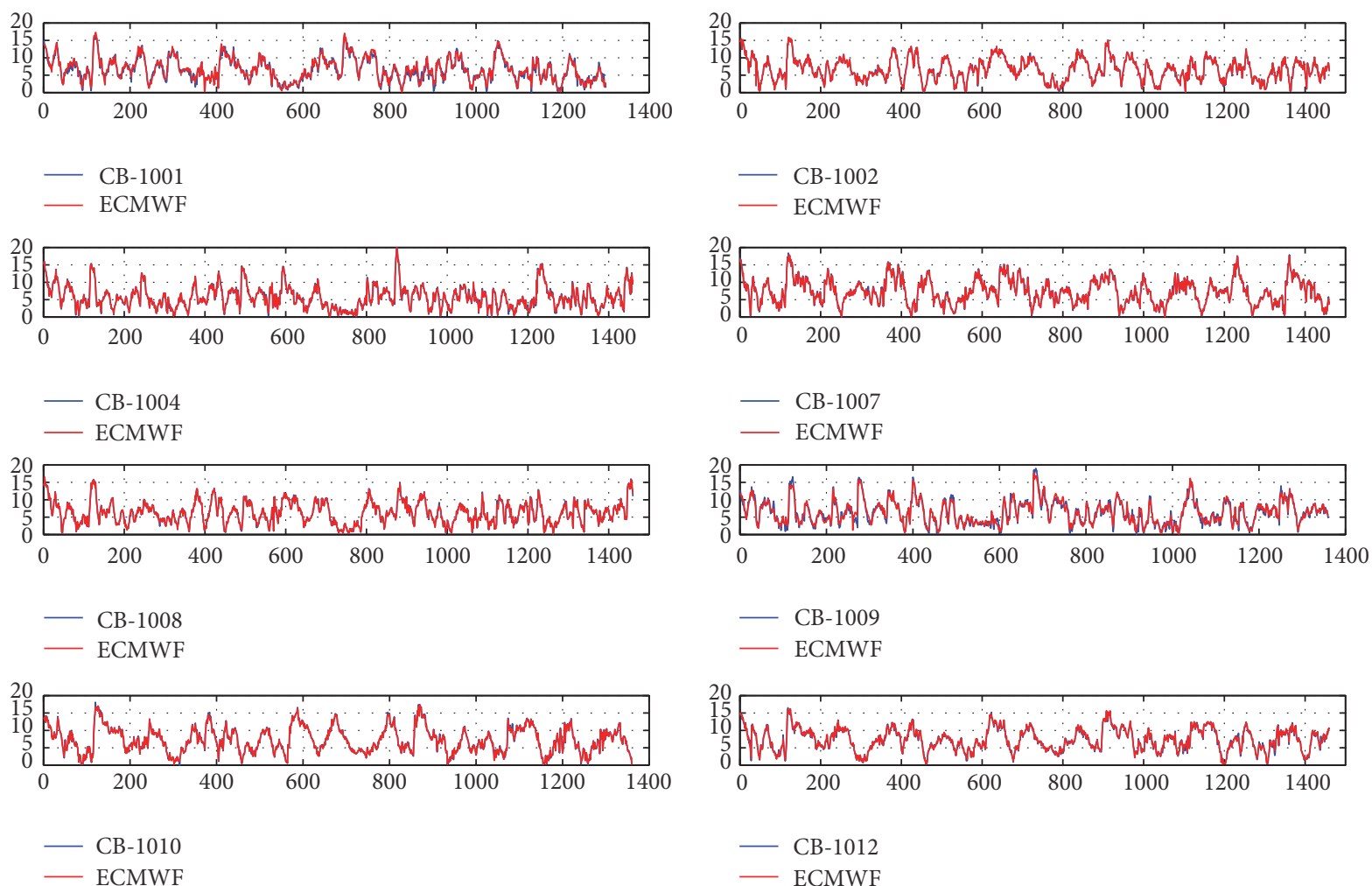

FIGURE 2: Time series of observed (buoy) and satellite (ECMWF) data for the wind speed for the period of 2015 around the ECS for stations CB-1001, 1002, 1004, 1007, 1008, 1009, 1010, and 1012.

is computed using approaches, such as standard deviation method [25], power density method [26], maximum likelihood method [27], and graphical method [28]. High value of " $k$ " represents stable wind speed. A larger value of " $c$ " indicates more spread of wind power [29]. Therefore, this study adopted standard deviation method, which is expressed in $[25,30]$ as

$$
\begin{aligned}
& k=-\left(\frac{\sigma}{\bar{v}}\right)^{-1.086} \text { for } 1 \leq k \leq 10 \\
& c=\frac{\bar{v}}{\Gamma(1+1 / k)},
\end{aligned}
$$

where $\bar{v}$ is the average wind speed $(\mathrm{m} / \mathrm{s})$ and $\sigma$ is the standard deviation that shows the extent of deviation of the wind speed. $\Gamma(x)$ is the gamma function expressed in [31] as

$$
\Gamma(x)=\int_{0}^{\infty} \exp (-u) u^{x-1} d x .
$$

Wind power density is expressed in [32] as

$$
P_{d}=\frac{P(v)}{A}=\frac{1}{2} \rho \int_{0}^{\infty} v^{3} f(v) d v=\frac{1}{2} \rho c^{3} \Gamma\left(1+\frac{3}{k}\right),
$$

where $P_{d}$ is the wind power density in $\mathrm{w} / \mathrm{m}^{2}, P(v)$ is the wind power in watts, $A$ is the swept area of the wind turbine rotor in $\mathrm{w} / \mathrm{m}^{2}$, and $\rho$ is the air density that is assumed as $1.225 \mathrm{~kg} / \mathrm{m}^{3}$.

The coefficient of variation (cov) indicates the mutability of wind speed and is the ratio between mean standard deviation and mean wind speed. cov is defined in percent and can be expressed in [33] as

$$
\operatorname{cov}(\%)=\frac{\sigma}{\bar{V}} \times 100 .
$$

In this study, wind speed data for 1980-2009 were statistically analyzed. The monthly and seasonal variations in the Weibull parameters, wind power density, mean wind speed, standard deviation, and cov were obtained. Furthermore, the spatial distribution of wind power density and its trends were analyzed.

3.2. Result and Discussion. This section discusses the monthly and seasonal characteristics of the $10 \mathrm{~m}$ wind speed and wind power density in the ECS. The variation in Weibull parameters and spatiotemporal trends of wind power were analyzed and discussed. Some findings from this paper were compared with those from previous studies.

3.2.1. Monthly Wind Pattern. The monthly mean values of the Weibull parameters, wind power density, wind speed, standard deviation, and coefficient of variation are listed in Table 2.

The shape parameter " $k$ " varies between 2.09 in August and 3.36 in December, which reveals that the wind speed data are most stable in December and least stable in August. Therefore, December is suitable for the production of uninterrupted and stable wind power. The scale parameter " $c$ " 
TABLE 2: Monthly and annual mean Weibull parameters, wind power density, wind speed, standard deviation, and coefficient of variation.

\begin{tabular}{|c|c|c|c|c|c|c|}
\hline Month & $k$ & $c(\mathrm{~m} / \mathrm{s})$ & WPD $\left(\mathrm{w} / \mathrm{m}^{2}\right)$ & $u(\mathrm{~m} / \mathrm{s})$ & $\sigma$ & $\operatorname{cov}(\%)$ \\
\hline Jan & 3.22 & 8.74 & 429.25 & 7.84 & 2.83 & 36.45 \\
\hline Feb & 2.94 & 8.22 & 374.72 & 7.34 & 2.92 & 39.98 \\
\hline Mar & 2.67 & 7.28 & 274.81 & 6.49 & 2.78 & 42.97 \\
\hline Apr & 2.62 & 6.38 & 192.24 & 5.68 & 2.53 & 44.65 \\
\hline May & 2.5 & 5.79 & 148.7 & 5.15 & 2.4 & 46.85 \\
\hline Jun & 2.55 & 6.08 & 174.57 & 5.42 & 2.54 & 47.2 \\
\hline Jul & 2.27 & 6.3 & 215.88 & 5.61 & 2.94 & 52.63 \\
\hline Aug & 2.09 & 6.47 & 257.97 & 5.76 & 3.26 & 56.64 \\
\hline Sep & 2.21 & 6.56 & 246.58 & 5.84 & 3.08 & 52.9 \\
\hline Oct & 2.77 & 7.76 & 342.15 & 6.93 & 2.99 & 43.75 \\
\hline Nov & 3.18 & 8.69 & 444.38 & 7.8 & 2.95 & 38.59 \\
\hline Dec & 3.36 & 9.17 & 504.21 & 8.24 & 2.94 & 36.51 \\
\hline Annual & 2.69 & 7.28 & 300.45 & 6.51 & 2.85 & 44.93 \\
\hline
\end{tabular}

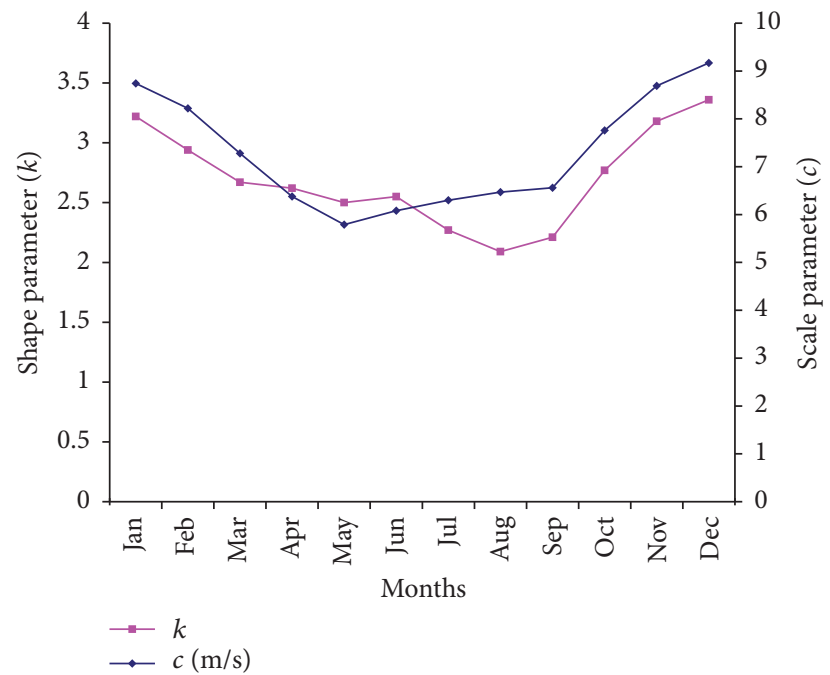

Figure 3: Values of monthly mean shape $(k)$ and scale $(c)$ parameters for the period 1980-2009 in the ECS, unit: $k$ (dimensionless), $c$ $(\mathrm{m} / \mathrm{s})$.

ranges between $5.79 \mathrm{~m} / \mathrm{s}$ in May and $9.17 \mathrm{~m} / \mathrm{s}$ in December. The monthly mean wind speed varies between $5.15 \mathrm{~m} / \mathrm{s}$ in May and $8.24 \mathrm{~m} / \mathrm{s}$ in December. The wind power density lies between $148.7 \mathrm{w} / \mathrm{m}^{2}$ in May and $504.21 \mathrm{w} / \mathrm{m}^{2}$ in December. These values are represented in Figures 3, 4, and 5.

The minimum and maximum values of cov are $36.45 \%$ in January and 56.64\% in August. The highest value in August reveals that the variation in wind speed is very high in August. The obtained maximum and minimum values of the standard deviation are equal to 2.4 and 3.26 in May and August, respectively.

The annual mean wind speed and wind power density were $6.51 \mathrm{~m} / \mathrm{s}$ and $300.45 \mathrm{w} / \mathrm{m}^{2}$, respectively. For the wind power classification proposed by [21] of Pacific Northwest Laboratory (Table 3), the annual mean power density for

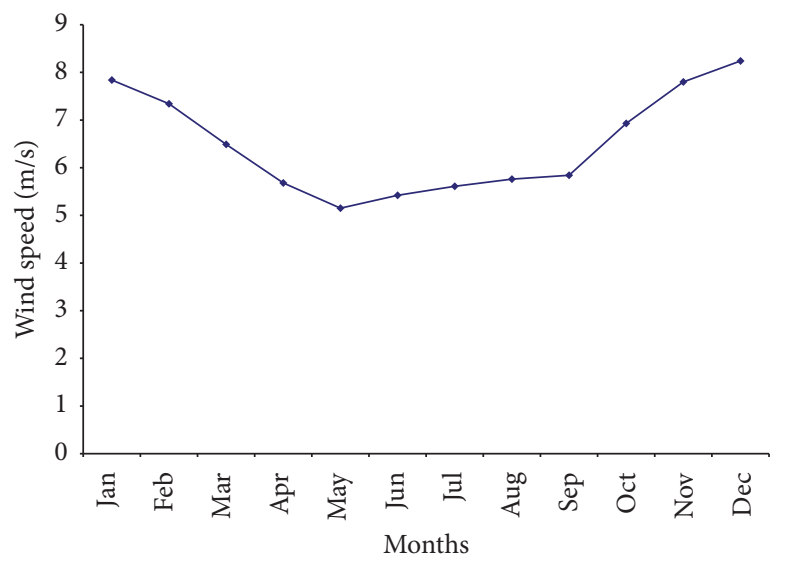

FIGURE 4: Values of monthly mean $10 \mathrm{~m}$ wind speed for the period 1980-2009 in the ECS, unit: $\mathrm{m} / \mathrm{s}$.

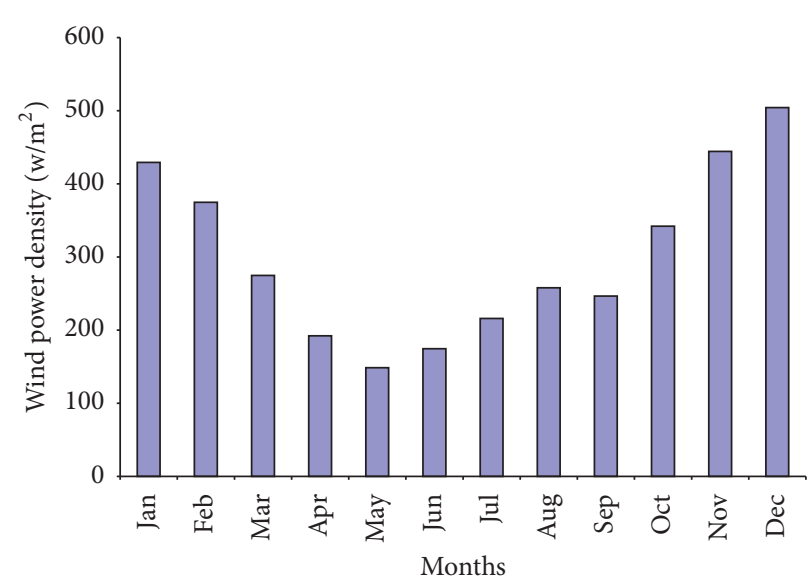

FIGURE 5: Values of monthly mean wind power density for the period 1980-2009 in the ECS calculated by the Weibull distribution, unit: $\mathrm{w} / \mathrm{m}^{2}$. 
TABLE 3: Wind power classification [21].

\begin{tabular}{lc}
\hline Power class & Power density $\left(\mathrm{w} / \mathrm{m}^{2}\right)$ at $10 \mathrm{~m}$ \\
\hline 1 & $0<P \leq 100$ \\
2 & $100<P \leq 150$ \\
3 & $150<P \leq 200$ \\
4 & $200<P \leq 250$ \\
5 & $250<P \leq 300$ \\
6 & $300<P \leq 400$ \\
7 & $400<P \leq 1000$ \\
\hline
\end{tabular}

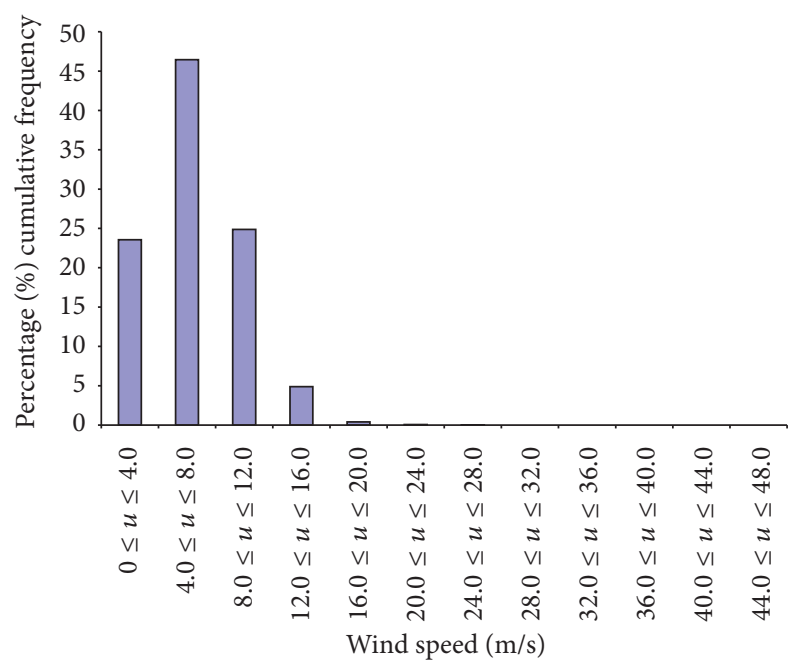

FIGURE 6: The percentage frequency distribution of wind speed obtained from the thirty-year (1980-2009) daily average wind speed data of ECS, unit: \%.

ECS is categorized as class 6; this classification indicates the excellent potential of ECS for large-scale wind power applications.

The percentage frequency distribution of wind speed in the ECS is illustrated in Figure 6. The wind speed within the range of $4-8 \mathrm{~m} / \mathrm{s}$ has the highest frequency of $46.45 \%$. The other wind speed categories of $0-4 \mathrm{~m} / \mathrm{s}$ and $8-12 \mathrm{~m} / \mathrm{s}$ have frequencies with a difference of $1.31 \%$, whereas the wind speed in the range of $12-16 \mathrm{~m} / \mathrm{s}$ has a low frequency of $4.88 \%$.

The percentage frequency distribution of wind speed in the ECS is illustrated in Figure 6. The wind speed within the range of $4-8 \mathrm{~m} / \mathrm{s}$ has the highest frequency of $46.45 \%$. The other wind speeds categories of $0-4 \mathrm{~m} / \mathrm{s}$ and $8-12 \mathrm{~m} / \mathrm{s}$, respectively, have frequencies that differ by $1.31 \%$ while the wind speed in the range of $12-16 \mathrm{~m} / \mathrm{s}$ has a low frequency of $4.88 \%$.

3.2.2. Seasonal Wind Pattern. The months in each season in China can be classified as follows: (1) winter is December to February; (2) spring is March to May; (3) summer is June to August; and (4) autumn is September to November. The seasonal mean values of the Weibull parameters, wind power density, wind speed, standard deviation, and coefficient of variation are listed in Table 4.
TABLE 4: Seasonal mean Weibull parameters, wind power density, wind speed, standard deviation, and coefficient of variation.

\begin{tabular}{lcccccc}
\hline Season & $k$ & $c(\mathrm{~m} / \mathrm{s})$ & WPD $\left(\mathrm{w} / \mathrm{m}^{2}\right)$ & $u(\mathrm{~m} / \mathrm{s})$ & $\sigma$ & $\operatorname{cov}(\%)$ \\
\hline Winter & 2.96 & 8.76 & 437.54 & 7.82 & 2.95 & 38.05 \\
Spring & 2.42 & 6.5 & 203.95 & 5.77 & 2.64 & 45.87 \\
Summer & 2.08 & 6.31 & 212.27 & 5.6 & 2.95 & 52.79 \\
Autumn & 2.39 & 7.72 & 343.25 & 6.86 & 3.15 & 46.23 \\
\hline
\end{tabular}

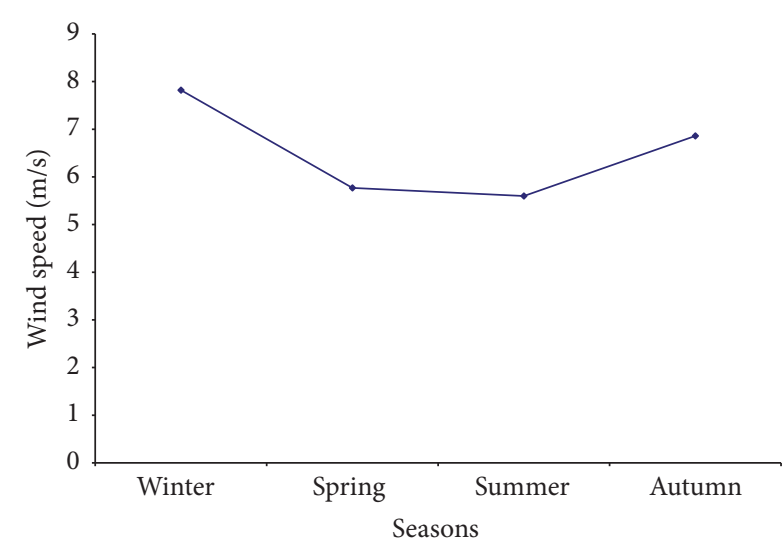

Figure 7: Values of seasonal mean $10 \mathrm{~m}$ wind speed for the period 1980-2009 in the ECS, unit: $\mathrm{m} / \mathrm{s}$.

The maximum and minimum values of the standard deviation were observed during autumn (3.15) and spring (2.64). The largest cov was observed during summer (52.79\%) and the lowest was detected during winter (38.05\%). The shape factor $(k)$ ranged between 2.08 during summer and 2.96 during winter. The scale factor $(c)$ ranged between $6.31 \mathrm{~m} / \mathrm{s}$ during summer and $8.76 \mathrm{~m} / \mathrm{s}$ during winter. The seasonal variation in the wind speed and wind power reveals that the maximum wind speed $(7.82 \mathrm{~m} / \mathrm{s})$ occurred in winter, whereas the minimum $(5.6 \mathrm{~m} / \mathrm{s})$ occurred during summer. In addition, the maximum wind power density $(437.54 \mathrm{w} /$ $\mathrm{m}^{2}$ ) was observed during winter, whereas the minimum $\left(203.95 \mathrm{w} / \mathrm{m}^{2}\right)$ occurred during spring. These results are shown in Figures 7 and 8.

Figures 9 and 10 show the dimensionless parameters used to further understand the characteristics of wind in ECS. These parameters are the ratios of monthly/seasonal mean wind speed and wind power density to the annual values of mean wind speed and wind power density.

Figure 9 shows that the peaks of the monthly-annual ratios of wind speed and wind power density occurred during December with values of 1.27 and 1.68, respectively. The minimum ratios of monthly to annual values of wind speed and wind power density occurred in May with values of 0.79 and 0.49 , respectively. Figure 10 also shows that the peaks of seasonal-annual ratio of wind speed and wind power density were observed during winter with values of 1.16 and 1.33 , respectively. The minimum ratio of the seasonal-annual values of wind speed occurred during summer with a value of 0.83 , and that of wind power density was observed during spring with a value of 0.62 . 


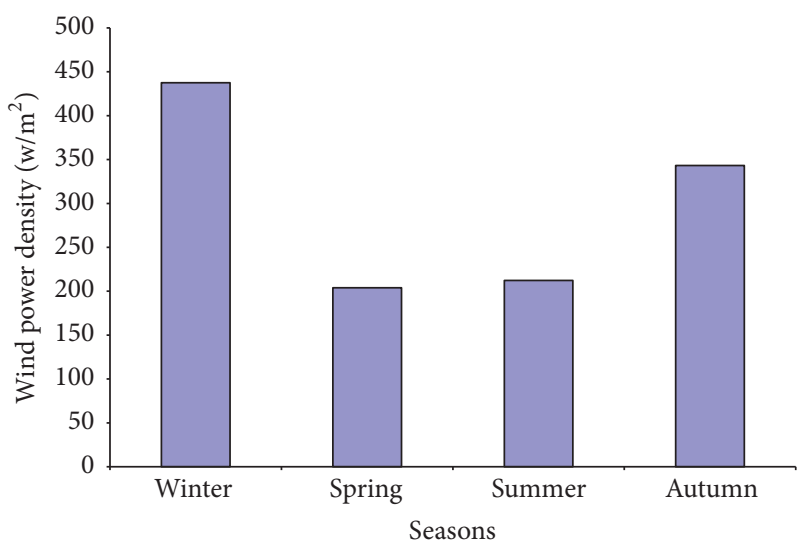

Figure 8: Values of seasonal mean wind power density for the period 1980-2009 in the ECS, unit: $\mathrm{w} / \mathrm{m}^{2}$.

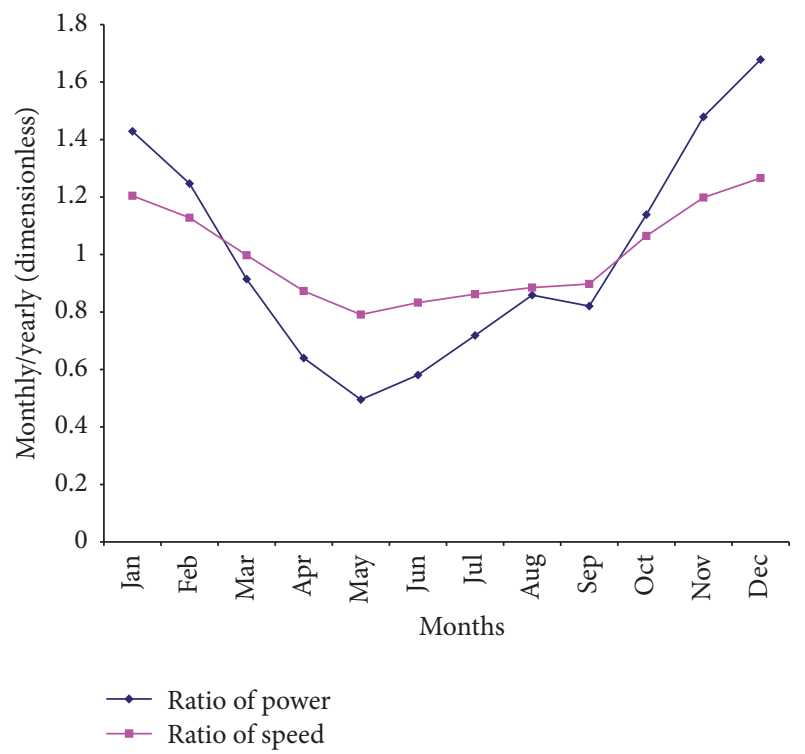

FIGURE 9: (Monthly/annual) ratio of mean wind power density and $10 \mathrm{~m}$ wind speed for the period 1980-2009 in the ECS.

3.2.3. Spatial Distribution of Wind Power Density. This section describes the regional distribution of wind power density and the locations with high potential for wind power applications in the ECS.

Figure 11(a) presents the annual mean distribution of wind power density in the ECS. The relatively large area of high wind power was distributed in regions surrounding the Taiwan Island in the southern ECS and in most parts of the ECS with values between $350 \mathrm{w} / \mathrm{m}^{2}$ and $580 \mathrm{w} / \mathrm{m}^{2}$. Locations such as Taiwan Strait and Taipei in southwest ECS with largest values of wind power between $550 \mathrm{w} / \mathrm{m}^{2}$ and $580 \mathrm{w} / \mathrm{m}^{2}$ exist in the high wind potential regions and have potential for large wind turbine installation.

Regions particularly Luzon and Taiwan Island in the southern ECS and some islands in the northeast ECS with wind power below $200 \mathrm{w} / \mathrm{m}^{2}$ do not show good wind characteristics. This finding reveals that these regions are not ideal

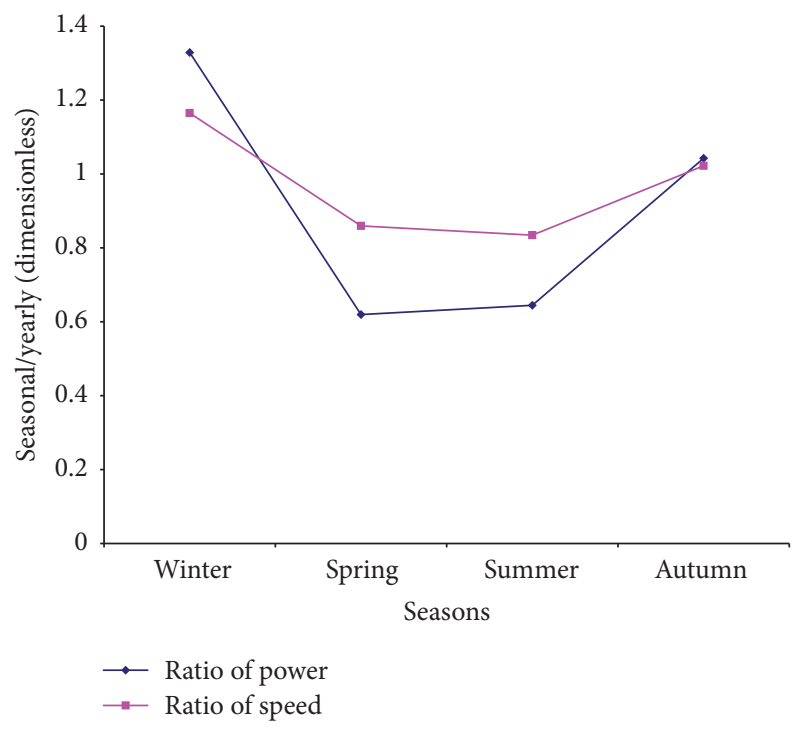

FIGURE 10: (Seasonal/annual) ratio of mean wind power density and $10 \mathrm{~m}$ wind speed for the period 1980-2009 in the ECS.

for grid-connected electricity production but might have sufficient wind for small wind turbines.

The seasonal mean variation in the wind power in the SCS is shown in Figure 11(b). Under the significant influence of the northeast trade wind caused by frequent and powerful cold air, the wind power during winter is greater (500$800 \mathrm{w} / \mathrm{m}^{2}$ ) and occupies a larger region of the ECS compared with that in the other seasons. Significantly high values (700$800 \mathrm{w} / \mathrm{m}^{2}$ ) were observed around Taipei and Taiwan Strait and also in some regions between Luzon and Taiwan Islands. Values lower than $200 \mathrm{w} / \mathrm{m}^{2}$ were distributed in waters close to Luzon and Taiwan Island and over Shikoku and Kyushu Islands in the northeast ECS.

The wind power during spring is slightly higher than that during summer but was lower than $350 \mathrm{w} / \mathrm{m}^{2}$ in most parts of the ECS. Relatively large area was distributed in the Northwest Pacific with wind power of $150-200 \mathrm{w} / \mathrm{m}^{2}$. Low wind power values (less than $100 \mathrm{w} / \mathrm{m}^{2}$ ) were observed in the Shikoku Island in Northeast ECS and also in Luzon and Taiwan Islands.

The wind power during summer is the lowest in the whole year, with values less than $330 \mathrm{w} / \mathrm{m}^{2}$ in every part of the ECS and surrounding regions. Relatively large area was distributed in the ECS. The wind power was strongest $\left(250-300 \mathrm{w} / \mathrm{m}^{2}\right)$ in the ECS and immediate waters. Low values around $150 \mathrm{w} / \mathrm{m}^{2}$ were observed in the Yellow Sea and over Taiwan and Luzon Islands.

The wind power during autumn is stronger than that during spring and summer. Values ranging between 300 and $400 \mathrm{w} / \mathrm{m}^{2}$ were distributed over most parts of the ECS and surrounding regions. Large values (450-620 w/ $\left.\mathrm{m}^{2}\right)$ were observed in the Bashi Channel Area and adjacent locations. The wind power around Taipei is the strongest with value of up to $800 \mathrm{w} / \mathrm{m}^{2}$. 

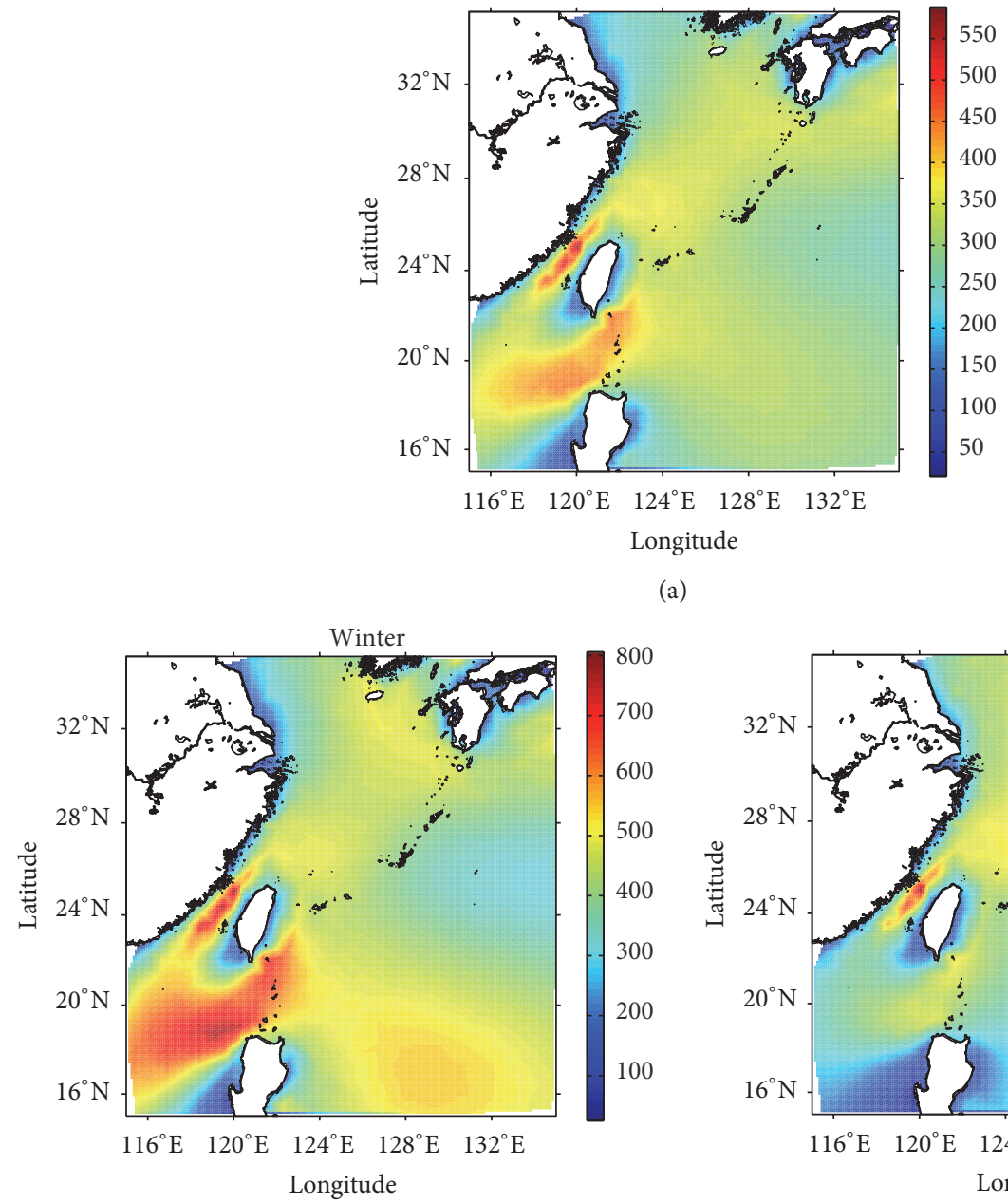

(a)
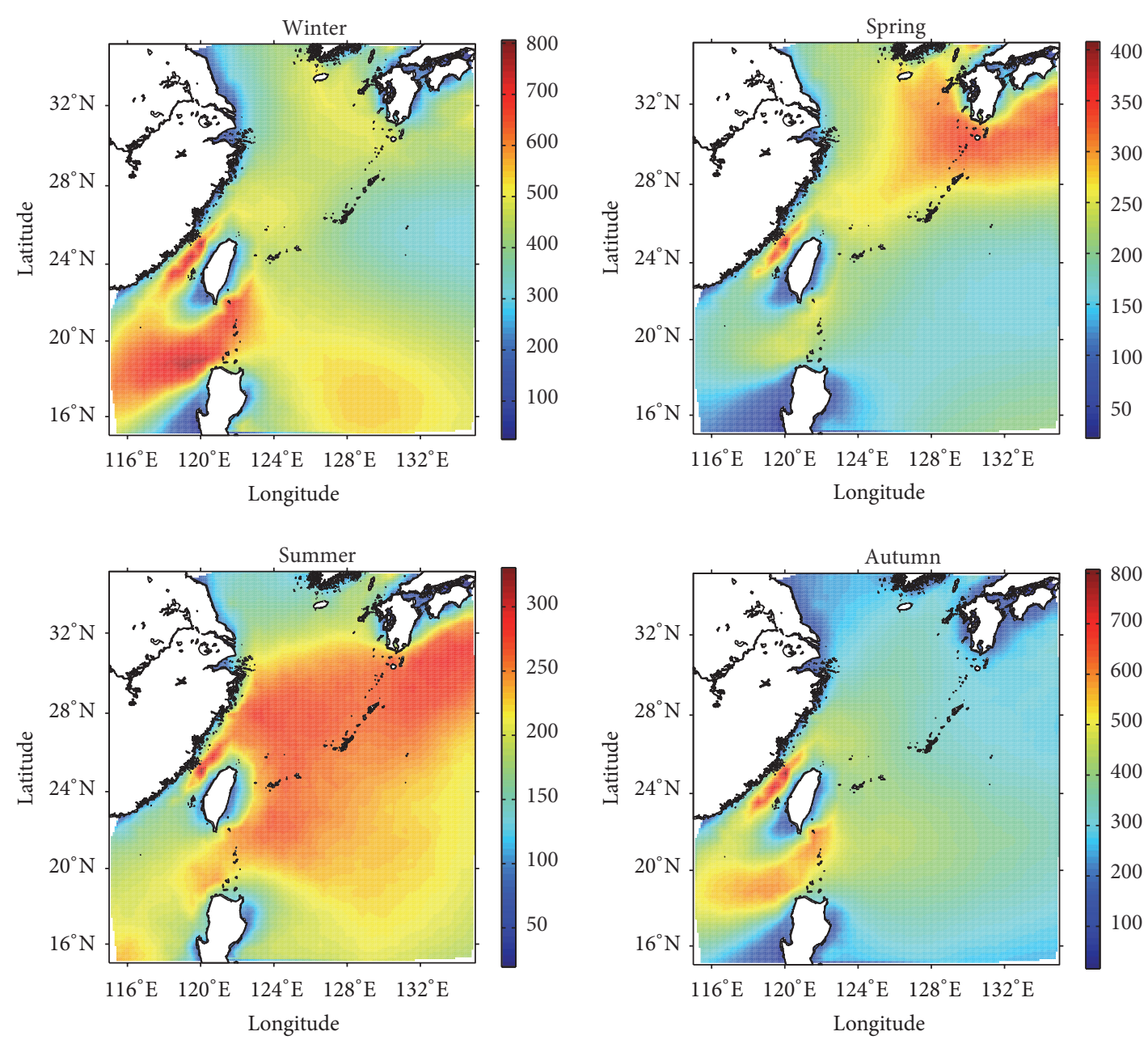

(b)

FIGURE 11: (a) Annual and (b) seasonal distribution of wind power density for the period 1980-2009 in the ECS. Values on the side bars are in $\mathrm{w} / \mathrm{m}^{2}$.

3.2.4. Spatial Trends in Wind Power Density. This section describes the regional variation of linear trends in wind power and identifies the locations with strong positive trends in the ECS.
The annual mean spatial trends in wind power are shown in Figure 12(a). Insignificant and decreasing trends in wind power $\left(0.5 \mathrm{w} / \mathrm{m}^{2} \mathrm{yr}^{-1}\right.$ to $\left.-1 \mathrm{w} / \mathrm{m}^{2} \mathrm{yr}^{-1}\right)$ were observed in most parts of ECS and surrounding regions. Increasing positive 


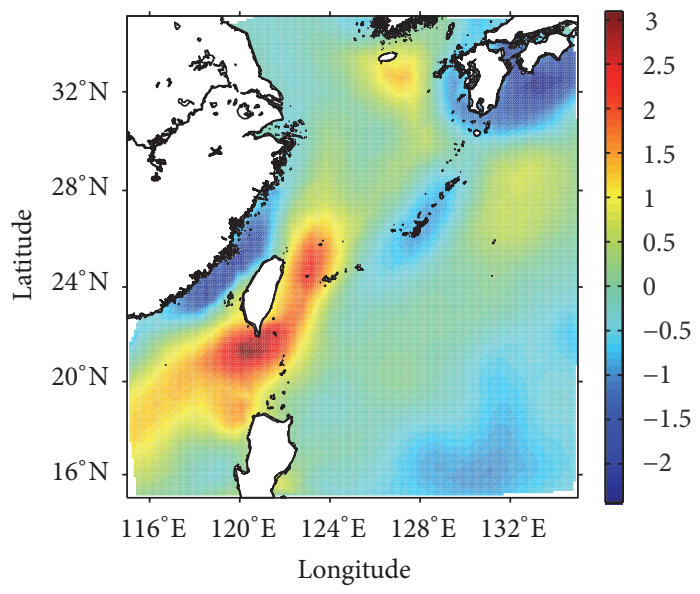

(a)
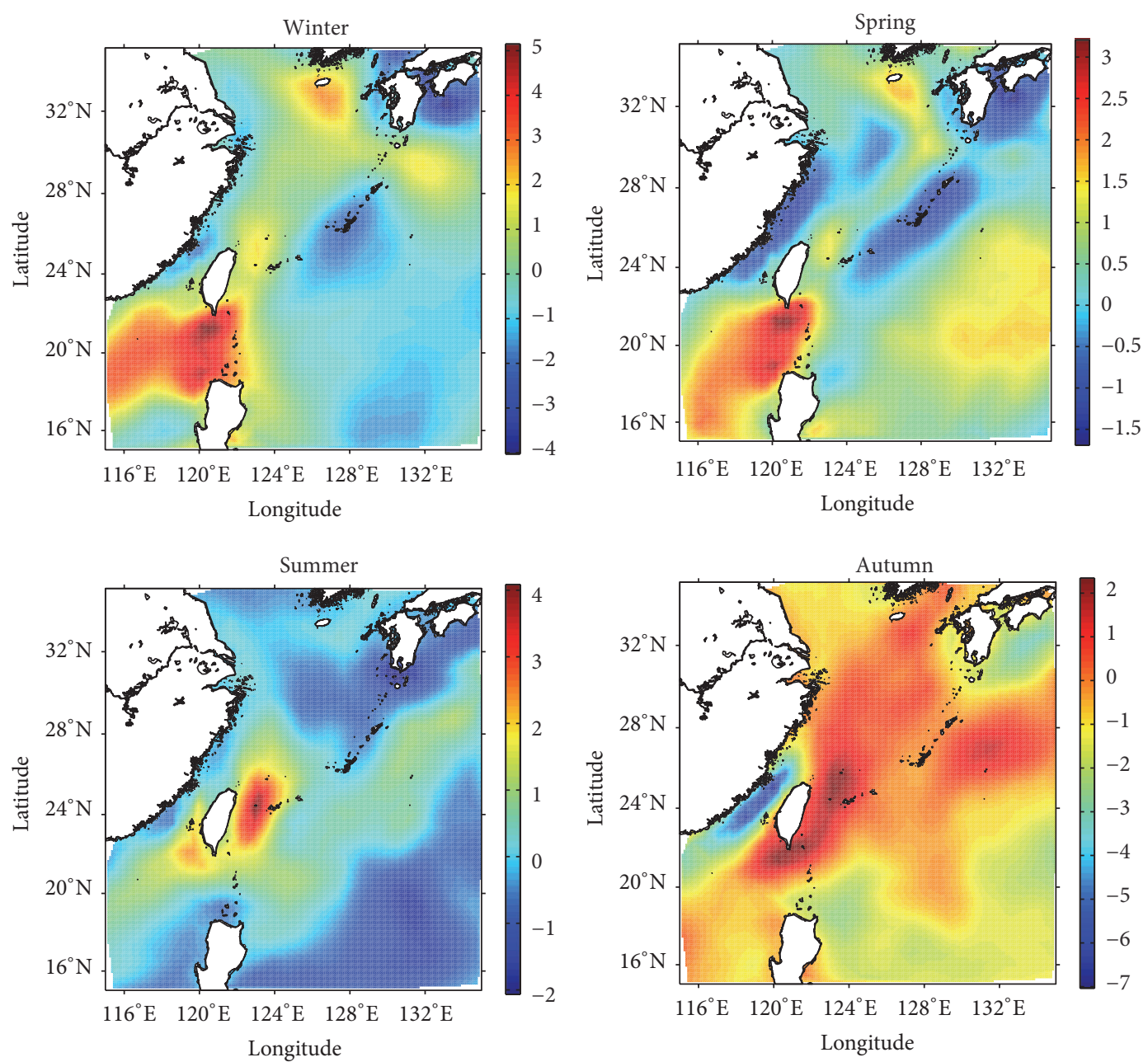

(b)

FIGURE 12: (a) Annual and (b) seasonal distribution of linear trends in wind power density for the period 1980-2009 in the ECS. Values on the side bars are in $\mathrm{w} / \mathrm{m}^{2} \mathrm{yr}^{-1}$.

trends $\left(1 \mathrm{w} / \mathrm{m}^{2} \mathrm{yr}^{-1}\right.$ to $\left.3 \mathrm{w} / \mathrm{m}^{2} \mathrm{yr}^{-1}\right)$ were distributed in the upper South China Sea and Ryukyu Islands, but the strongest was observed in the Bashi Channel. Positive trends of approximately $1 \mathrm{w} / \mathrm{m}^{2} \mathrm{yr}^{-1}$ were also observed around Jeju
Island in the ECS and in southern Kyushu-Palau Ridge. Decreasing trends of less than $-1.5 \mathrm{w} / \mathrm{m}^{2} \mathrm{yr}^{-1}$ were found in Taipei, Taiwan Strait, and some northeastern islands such as Kyushu and Shikoku. 
As shown in Figure 12(b), the long-term trend in wind power exhibited great seasonal differences. The area extent of the significant wind power increase was the largest during winter, reduced during spring and summer, and the smallest during autumn.

Insignificant and decreasing trends in wind power of less than $1 \mathrm{w} / \mathrm{m}^{2} \mathrm{yr}^{-1}$ during winter dominated most parts of ECS and surrounding regions. Increasing positive trends $\left(1 \mathrm{w} / \mathrm{m}^{2} \mathrm{yr}^{-1}\right.$ to $\left.5 \mathrm{w} / \mathrm{m}^{2} \mathrm{yr}^{-1}\right)$ were distributed around the upper South China Sea and Bashi Channel. Positive trends were also found in Jeju Island and the immediate south of Kyushu Island.

During spring, areas with significant increase in wind power $\left(2 \mathrm{w} / \mathrm{m}^{2} \mathrm{yr}^{-1}\right.$ to $\left.3.2 \mathrm{w} / \mathrm{m}^{2} \mathrm{yr}^{-1}\right)$ extended from Luzon Strait to Bashi Channel in Northern South China Sea. Trends between 1 and $1.5 \mathrm{w} / \mathrm{m}^{2} \mathrm{yr}^{-1}$ dominated a large part of the Northwest Pacific Ocean and Jeju Island. Strong decreasing trends of up to $-1.5 \mathrm{w} / \mathrm{m}^{2} \mathrm{yr}^{-1}$ were observed around Taiwan Strait, Taipei, Okinawa, and islands of Ryukyu and Shikoku.

During summer, regions with strong positive trends $\left(2 \mathrm{w} / \mathrm{m}^{2} \mathrm{yr}^{-1}\right.$ to $\left.4 \mathrm{w} / \mathrm{m}^{2} \mathrm{yr}^{-1}\right)$ were found in immediate waters surrounding the Taiwan Island. The trends in wind power were insignificant and negative with values less than $1 \mathrm{w} / \mathrm{m}^{2} \mathrm{yr}^{-1}$ in the rest of the regions. Strong negative trends of up to $-2 \mathrm{w} / \mathrm{m}^{2} \mathrm{yr}^{-1}$ occurred in a large part of Northwest Pacific and some islands in the northeastern part of ECS.

During autumn, positive but weak trends $\left(1 \mathrm{w} / \mathrm{m}^{2} \mathrm{yr}^{-1}\right.$ to $2 \mathrm{w} / \mathrm{m}^{2} \mathrm{yr}^{-1}$ ) were distributed in the ECS, southern KyushuPalau Ridge, and sporadic waters close to Taiwan Island. Negative trends dominated the remaining regions, and the strongest values of up to $-7 \mathrm{w} / \mathrm{m}^{2} \mathrm{yr}^{-1}$ were observed around Taiwan Strait.

3.2.5. Temporal Trends in Wind Power Density. This section describes the overall long-term trends in the annual and seasonal average wind power analyzed using linear regression method with reliability test result of $95 \%$.

The annual mean wind power was obtained by computing the regional average wind power from 00:00 UTC on January 1, 1976, to 18:00 UTC on December 31, 2005. Thirty regional and yearly average values of the ECS wind power were obtained using the same method to analyze the overall long-term trend for 1976-2005 (Figure 13(a)). The overall seasonal variation in the ECS wind power was also analyzed (Figure 13(b)). Figure 13(a) shows that the regression coefficient is 0.031 . Specifically, the ECS wind power insignificantly increased by $0.031 \mathrm{w} / \mathrm{m}^{2} \mathrm{yr}^{-1}$ during $1976-2005$. For the seasons, the ECS wind power significantly increased by $0.59 \mathrm{w} / \mathrm{m}^{2} \mathrm{yr}^{-1}$ during spring in 1976-2005. Similarly, the ECS wind power increased by $0.11 \mathrm{w} / \mathrm{m}^{2} \mathrm{yr}^{-1}$ during winter and $0.012 \mathrm{w} / \mathrm{m}^{2} \mathrm{yr}^{-1}$ during summer. A decreasing trend of $-0.68 \mathrm{w} / \mathrm{m}^{2} \mathrm{yr}^{-1}$ was observed during autumn. The increase in the ECS wind power was strongest during spring, followed by winter, summer, and autumn.

Table 5 presents a 5 -year trend in wind power density for the whole year and for the seasons. The corresponding graphical plots are shown in Figure 14. Within the study
TABLE 5: 5-year trends of wind power for the year and seasons.

\begin{tabular}{lccccc}
\hline Year & Annual & Winter & Spring & Summer & Autumn \\
\hline $1980-1984$ & -3.11 & -3.99 & -5.16 & 8.88 & -12.96 \\
$1984-1988$ & -0.26 & 1.2 & 1.62 & -16.76 & 14.53 \\
$1988-1992$ & -3.58 & -25.5 & -20.91 & 12.92 & 20.78 \\
$1992-1996$ & 11.98 & 19.79 & 25.21 & 4.65 & -4.08 \\
$1996-2000$ & -0.83 & 21.82 & -5.25 & -5.41 & -14.13 \\
$2000-2004$ & -7.1 & -23.97 & -3.02 & -7.31 & 5.71 \\
$2004-2009$ & -6.52 & 4.68 & -3.77 & -12.41 & -14.1 \\
\hline
\end{tabular}

period, an increasing trend in wind power $\left(11.98 \mathrm{w} / \mathrm{m}^{2} \mathrm{yr}^{-1}\right)$ only occurred between 1992 and 1996, whereas a negative trend occurred in the remaining years. The strongest negative trend in wind power $\left(-6.52 \mathrm{w} / \mathrm{m}^{2} \mathrm{yr}^{-1}\right)$ was observed between 2004 and 2009.

A positive trend of $21.82 \mathrm{w} / \mathrm{m}^{2} \mathrm{yr}^{-1}$ in wind power was most significant between 1996 and 2000 during winter. Negative trends of $-3.99,-25.5$, and $-23.97 \mathrm{w} / \mathrm{m}^{2} \mathrm{yr}^{-1}$ occurred within 1980-1984, 1988-1992, and 2000-2004, respectively.

During spring, a strong positive trend of $25.21 \mathrm{w} / \mathrm{m}^{2} \mathrm{yr}^{-1}$ was observed between 1992 and 1996. Decreasing trends of $-5.16,-20.91,-5.25,-3.02$, and $-3.77 \mathrm{w} / \mathrm{m}^{2} \mathrm{yr}^{-1}$ occurred within 1980-1984, 1988-1992, 1996-2000, 2000-2004, and 2004-2009, respectively.

During summer, the strongest trend of $12.92 \mathrm{w} / \mathrm{m}^{2} \mathrm{yr}^{-1}$ was observed in 1988-1992. Negative trends of $-16.76,-5.41$, -7.31 , and $-12.41 \mathrm{w} / \mathrm{m}^{2} \mathrm{yr}^{-1}$ were observed within 1984-1988, 1996-2000, 2000-2004, and 2004-2009, respectively.

During autumn, the most significant trend of $20.78 \mathrm{w} /$ $\mathrm{m}^{2} \mathrm{yr}^{-1}$ occurred within 1988-1992. Decreasing trends of $-12.96,-4.08,-14.13$, and $-14.1 \mathrm{w} / \mathrm{m}^{2} \mathrm{yr}^{-1}$ occurred in 19801984, 1992-1996, 1996-2000, and 2004-2009, respectively.

3.2.6. Comparison of Wind Energy Potentials in the ECS with Some Other Previous Studies. The results of this study were compared with the offshore wind speed and wind power characteristics for 10 locations in the Aegean and Ionian Seas using the 3-hour buoy data between 3.1 and 11 years from each location [13]. The annual mean wind power density analyzed at a hub height of $50 \mathrm{~m}$ at Lesvos $\left(693 \mathrm{~W} / \mathrm{m}^{2}\right)$ classified and rated the location as wind class 6 and as an outstanding site for wind energy generation. In terms of wind power class, the wind energy potential at Lesvos is similar to that of ECS $\left(300.45 \mathrm{~W} / \mathrm{m}^{2}\right)$ as both stand at class 6 and are rated as excellent sites suitable for the exploitation of wind energy even at different hub heights. A comparison in terms of the annual mean coefficient of variation of $10 \mathrm{~m}$ wind speed between the 10 locations and ECS showed that location E1M3A in the Aegean Sea exhibited an annual mean coefficient of variation (51.8\%) that is similar to that of ECS (44.93\%) compared with the rest of the locations. Locations such as E1M3A, Mykonos, Petrokarovo, Santorini, and Skyros in the Aegean Sea and Zakynthos and Kalamata in the Ionian Sea exhibited nearly the same trend with ECS in the monthly variation of wind speed. Peak values in wind speed were observed in winter 


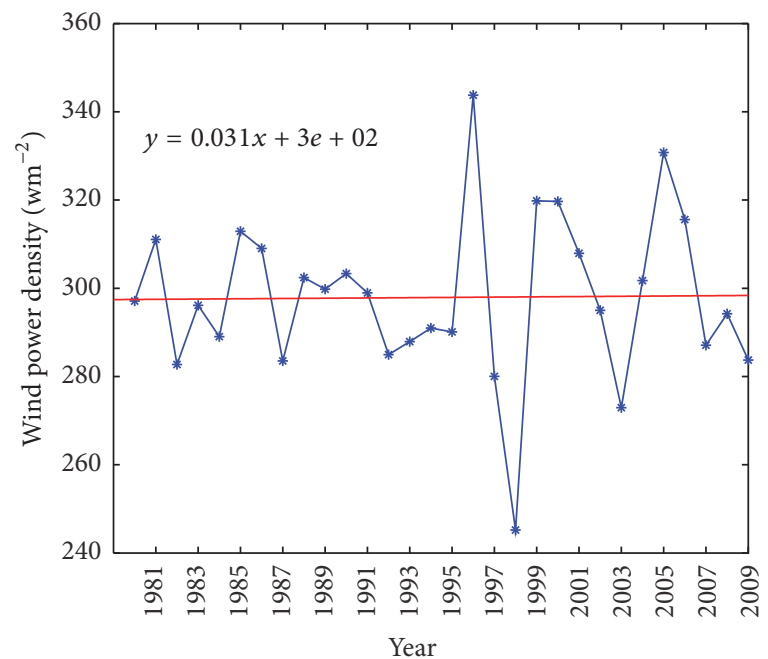

(a)
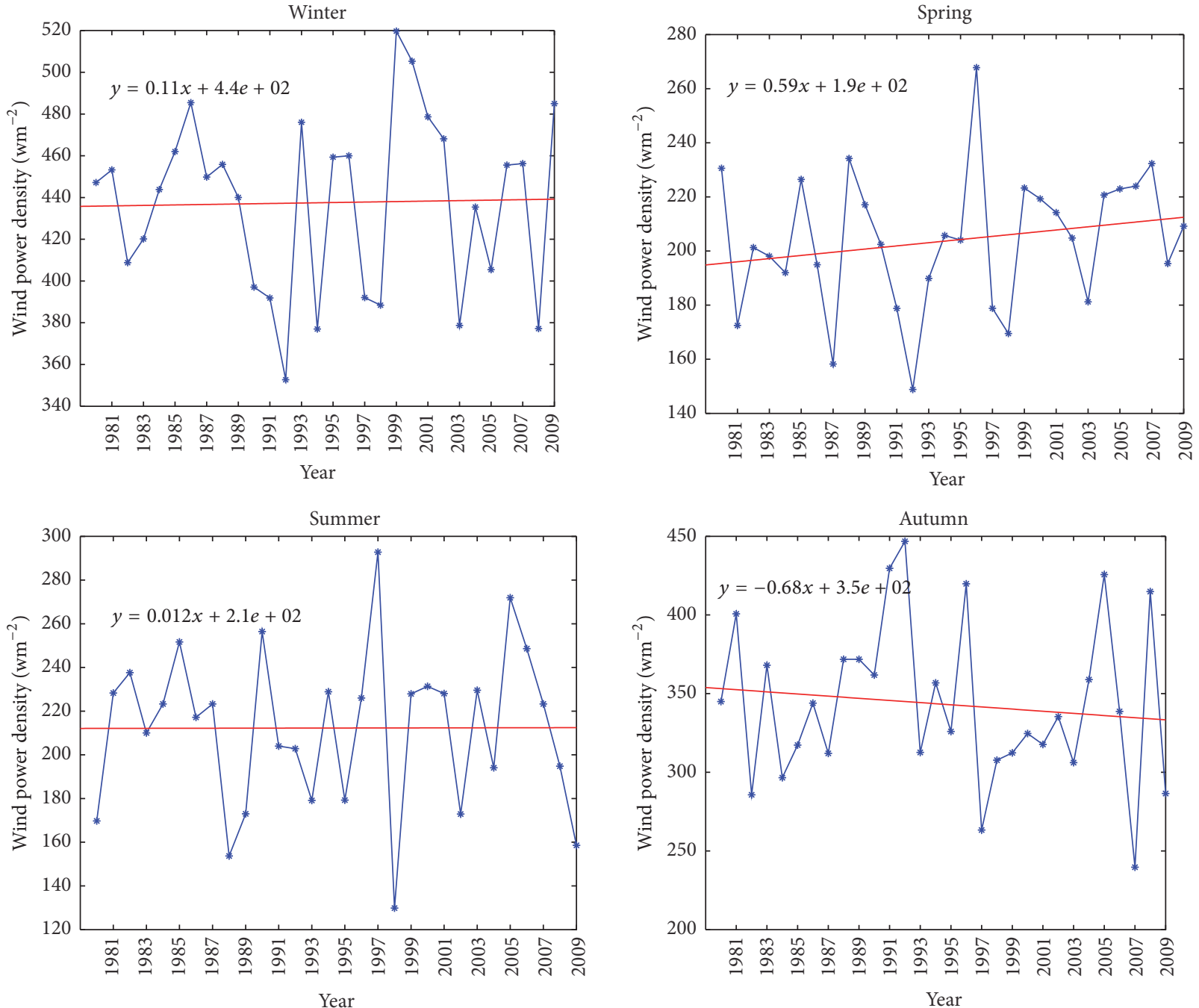

(b)

FIGURE 13: (a) Annual and (b) seasonal temporal trends in wind power density for the period 1980-2009 in the ECS, unit: $\mathrm{w} / \mathrm{m}^{2} \mathrm{yr} \mathrm{r}^{-1}$. 


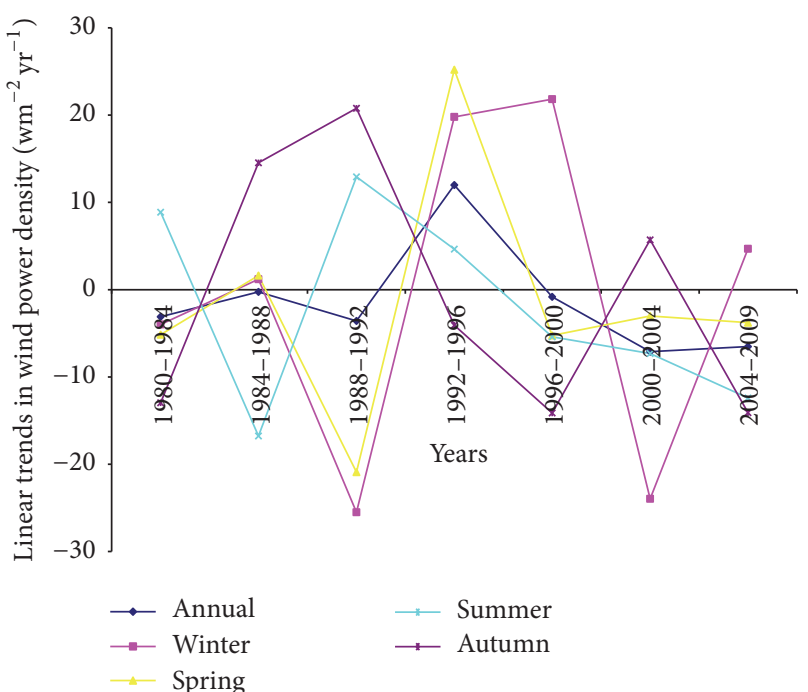

Figure 14: 5-year (1980-1984, 1984-1988, 1988-1992, 1992-1996, 1996-2000, 2000-2004, and 2004-2009) variation of wind power density for the year and seasons in the ECS, unit: $\mathrm{w} / \mathrm{m}^{2} \mathrm{yr}^{-1}$.

months of December and January, whereas the lowest values were found in May. At a hub height of $90 \mathrm{~m}$, the annual mean wind speed of Petrokaravo in the Aegean Sea $(7.1 \mathrm{~m} / \mathrm{s})$ is similar to the total time wind speed of ECS $(6.51 \mathrm{~m} / \mathrm{s})$ compared with the rest stations. The wind speed differs by $0.59 \mathrm{~m} / \mathrm{s}$.

The spatial distribution in the annual mean wind power density in the ECS was compared with that obtained from offshore $10 \mathrm{~m}$ wind speeds in Southern Europe, which covers the entire Mediterranean Sea for a 20-year period [14]. The results show that the Gulf of Lion in the Mediterranean Sea belongs to the same wind power class (greater than $550 \mathrm{~W} / \mathrm{m}^{2}$ ) as Taipei and Taiwan Strait in the ECS. Regions, such as Gibraltar Strait, the strait between Sardinia and Corsica, and the Aegean Sea, in the Mediterranean Sea, have nearly the same wind energy potentials within $350-550 \mathrm{~W} / \mathrm{m}^{2}$ compared with regions in the ECS, such as Senkako Shoto, Ryuku Islands, Okinawa, Jeju Islands, Kagoshima, waters immediate south of Kyushu and Shikoku islands, Bashi Channel, and Philippine Basin. Regions of high wind power in the ECS have comparable wind energy potentials with that of the northwest Spanish Coast in the Atlantic region.

Total time comparison was conducted between the wind energy potential of the most promising locations, such as Taipei and Taiwan Strait, in the ECS and the Crimean peninsula with Kazakhstan, which are regions of high wind energy in the northwestern part of Black Sea and northeastern part of Caspian Sea [15]. Results showed that Taipei and Taiwan Strait have higher values of wind power densities (greater than $550 \mathrm{~W} / \mathrm{m}^{2}$ ) than those of the Crimean peninsula and Kazakhstan (low values of $319.6 \mathrm{~W} / \mathrm{m}^{2}$ and $314 \mathrm{~W} / \mathrm{m}^{2}$ ) and are therefore considered as suitable locations for the installation of wind turbines. Wind power densities $\left(300 \mathrm{~W} / \mathrm{m}^{2}\right.$ and $330 \mathrm{~W} / \mathrm{m}^{2}$ ) observed over the waters in the Northwest Pacific, Jeju Islands, and some sporadic regions in the extreme northeast ECS have similar wind energy potential to those in
Crimean peninsula and Kazakhstan. Furthermore, a winter time comparison shows that regions, such as Taipei, Taiwan Strait, and waters in the Bashi Channel, with the largest values of wind power in the ECS $\left(700-800 \mathrm{~W} / \mathrm{m}^{2}\right)$ exhibited higher wind energy potential than Crimean peninsula and Kazakhstan $\left(436.9 \mathrm{~W} / \mathrm{m}^{2}\right.$ and $\left.426.3 \mathrm{~W} / \mathrm{m}^{2}\right)$. Waters on the immediate south of Kyushu and Shikoku islands in northeast ECS have similar wind energy potentials to those in Crimean peninsula and Kazakhstan.

Similar characteristics were observed in the monthly evaluation of both wind speed and wind power in Crimean peninsula and Kazakhstan with those of ECS as a whole. The highest values occurred in October to March, whereas the least values were observed in May. For both the ECS and the Crimean peninsula with Kazakhstan, an overall average of the total and winter time wind characteristics showed that higher values of wind speed and wind power density were generally observed during winter.

\section{Conclusion}

This study used a 30-year, 6-hour, high-resolution reanalysis of the wind field dataset to assess the spatiotemporal variation of the wind power potential using Weibull shape and scale parameters of the ECS. The major findings in this work are as follows:

(1) The region generally showed good wind characteristics. This finding is indicated by the high values for the monthly and annual mean wind speeds and power densities for the period of study.

(2) The calculated annual mean wind power resource $\left(300.45 \mathrm{w} / \mathrm{m}^{2}\right)$ reveals the excellent potential of the region for large-scale grid-connected wind turbine applications.

(3) The maximum wind speed of $8.24 \mathrm{~m} / \mathrm{s}$ occurred in December and the minimum of $5.15 \mathrm{~m} / \mathrm{s}$ occurred in May. The wind power ranged between $148.7 \mathrm{w} / \mathrm{m}^{2}$ in May and $504.21 \mathrm{w} / \mathrm{m}^{2}$ in December. The wind has the highest variation (56.64\%) in August and the lowest (36.45\%) in January.

(4) The maximum wind speed of $7.82 \mathrm{~m} / \mathrm{s}$ occurred during winter and the minimum of $5.6 \mathrm{~m} / \mathrm{s}$ occurred during summer. The wind power ranged between $203.95 \mathrm{w} / \mathrm{m}^{2}$ during spring and $437.54 \mathrm{w} / \mathrm{m}^{2}$ during winter. The wind has the highest variation $(52.79 \%)$ during summer and the lowest (38.05\%) during winter.

(5) The wind power is generally stronger in the southwestern part of the ECS. Strongest wind power density was observed around Taiwan Strait, Taipei, Bashi Channel, and adjacent waters, which rates these locations as excellent for installation of large wind turbines for electrical energy generation.

(6) Increasing positive trends in wind power density were distributed in the regions surrounding Taiwan 
Island. Insignificant and negative trends dominated the remaining regions.

(7) The wind power density exhibited an insignificant trend of $0.031 \mathrm{w} / \mathrm{m}^{2} \mathrm{yr}^{-1}$ in the ECS as a whole throughout the study period. The trend was the strongest $\left(0.59 \mathrm{w} / \mathrm{m}^{2} \mathrm{yr}^{-1}\right)$ during spring and the weakest $\left(-0.68 \mathrm{w} / \mathrm{m}^{2} \mathrm{yr}^{-1}\right)$ during autumn.

\section{Competing Interests}

The authors declare that they have no competing interests.

\section{Acknowledgments}

The authors of this paper sincerely thank the South China Sea Institute of Oceanology, Chinese Academy of Sciences for providing the wind fields data.

\section{References}

[1] H. Lund, "Large-scale integration of optimal combinations of $\mathrm{PV}$, wind and wave power into the electricity supply," Renewable Energy, vol. 31, no. 4, pp. 503-515, 2006.

[2] X. Sun, D. Huang, and G. Wu, "The current state of offshore wind energy technology development," Energy, vol. 41, no. 1, pp. 298-312, 2012.

[3] EWEA (European Wind Energy Association), Wind in our sails: the coming of Europe's offshore wind energy industry, 2011, http://www.ewea.org.

[4] L. Landberg, L. Myllerup, O. Rathmann et al., "Wind resource estimation-an overview," Wind Energy, vol. 6, no. 3, pp. 261271, 2003.

[5] A. M. Sempreviva, R. J. Barthelmie, and S. C. Pryor, "Review of methodologies for offshore wind resource assessment in European seas," Surveys in Geophysics, vol. 29, no. 6, pp. 471-497, 2008.

[6] C. B. Hasager, A. Peña, M. B. Christiansen et al., "Remote sensing observation used in offshore wind energy," IEEE Journal of Selected Topics in Applied Earth Observations and Remote Sensing, vol. 1, no. 1, pp. 67-79, 2008.

[7] H. G. Matthies and A. Garrad, "Study of offshore wind energy in the EC. JOULE (JOUR0072)," Report to the European Commission, Germanischer Lloyd, Hamburg, Germany, 1993.

[8] B. Bailey, S. Brennan, B. Kinal, M. Markus, and J. Kreiselman, Long Islands Offshore Wind Energy Development Potential: Phase 1. Preliminary, Assessment, AWS Scientific, 2002.

[9] EWEA 2010 Statistics, Offshore and eastern Europe new growth drivers for wind power in Europe, http://www.ewea.org/index .php?id $=60 \&$ no cache $=1 \&$ tx ttnews $[\mathrm{tt}$ news] $=1896 \& \mathrm{tx}$ ttnews[backPid] $=1 \&$ cHash=8b64626e4bf6996eea71ec3c08994b0a.

[10] F. Pimenta, W. Kempton, and R. Garvine, "Combining meteorological stations and satellite data to evaluate the offshore wind power resource of Southeastern Brazil," Renewable Energy, vol. 33, no. 11, pp. 2375-2387, 2008.

[11] E. D. Stoutenburg, N. Jenkins, and M. Z. Jacobson, "Power output variations of co-located offshore wind turbines and wave energy converters in California," Renewable Energy, vol. 35, no. 12, pp. 2781-2791, 2010.
[12] D. Karamanis, C. Tsabaris, K. Stamoulis, and D. Georgopoulos, "Wind energy resources in the Ionian Sea," Renewable Energy, vol. 36, no. 2, pp. 815-822, 2011.

[13] H. S. Bagiorgas, G. Mihalakakou, S. Rehman, and L. M. AlHadhrami, "Offshore wind speed and wind power characteristics for ten locations in Aegean and Ionian Seas," Journal of Earth System Science, vol. 121, no. 4, pp. 975-987, 2012.

[14] M. Menendez, M. García-Díez, L. Fita, J. Fernández, F. J. Méndez, and J. M. Gutiérrez, "High-resolution sea wind hindcasts over the Mediterranean area," Climate Dynamics, vol. 42, no. 7-8, pp. 1857-1872, 2014.

[15] F. Onea, A. Raileanu, and E. Rusu, "Evaluation of the wind energy potential in the coastal environment of two enclosed seas," Advances in Meteorology, vol. 2015, Article ID 808617, 14 pages, 2015.

[16] J. Jang, B. Yu, K. Ryu, and J. Lee, “Offshore wind resource assessment around korean peninsula by using QuikSCAT satellite data," Journal of the Korean Society for Aeronautical \& Space Sciences, vol. 37, no. 11, pp. 1121-1130, 2009.

[17] H. G. Kim, J. Choi, H. Lee, and W. Jung, "Study on the establishment of a wind map of the Korean Peninsula (I. Establishment of a synoptic wind map using remote-sensing data)," Journal of the Korean Society for New and Renewable Energy, vol. 1, no. 1, pp. 1-10, 2005.

[18] H. G. Kim, M. S. Jang, N. H. Kyong, H. W. Lee, H. K. Choi, and D. H. Kim, "Establishment of the low-resolution national wind map by numerical wind simulation," Journal of the Korean Solar Energy Society, vol. 26, no. 4, pp. 31-38, 2006.

[19] G. Xydis, C. Koroneos, and M. Loizidou, "Exergy analysis in a wind speed prognostic model as a wind farm sitting selection tool: a case study in Southern Greece," Applied Energy, vol. 86, no. 11, pp. 2411-2420, 2009.

[20] D. S. Wilks, Statistical Methods in the Atmospheric Sciences: An Introduction, Academic Press, San Diego, Calif, USA, 1995.

[21] D. Elliott and M. Schwartz, "Wind energy potential in the United States," Tech. Rep. PNL-SA-23109, Pacific Northwest Laboratory, Richland, Wash, USA, 1993.

[22] I. Fyrippis, P. J. Axaopoulos, and G. Panayiotou, "Wind energy potential assessment in Naxos Island, Greece," Applied Energy, vol. 87, no. 2, pp. 577-586, 2010.

[23] O. S. Ohunakin, M. S. Adaramola, and O. M. Oyewola, "Wind energy evaluation for electricity generation using WECS in seven selected locations in Nigeria," Applied Energy, vol. 88, no. 9, pp. 3197-3206, 2011.

[24] M. Gökçek, A. Bayülken, and Ş. Bekdemir, "Investigation of wind characteristics and wind energy potential in Kirklareli, Turkey," Renewable Energy, vol. 32, no. 10, pp. 1739-1752, 2007.

[25] C. G. Justus, W. R. Hargraves, A. Mikhail, and D. Graber, "Methods for estimating wind speed frequency distributions," Journal of Applied Meteorology, vol. 17, no. 3, pp. 350-353, 1978.

[26] S. A. Akdağ and A. Dinler, "A new method to estimate Weibull parameters for wind energy applications," Energy Conversion and Management, vol. 50, no. 7, pp. 1761-1766, 2009.

[27] M. Stevens and P. Smulders, "The estimation of the parameters of the Weibull wind speed distribution for wind energy utilization purposes," Wind Engineering, vol. 3, pp. 132-145, 1979.

[28] H. Rinne, The Weibull Distribution: A Handbook, CRC Press, 2010.

[29] J. K. Khan, F. Ahmed, Z. Uddin et al., "Determination of Weibull parameter by four numerical methods and prediction of wind speed in Jiwani (Balochistan)," Journal of Basic \& Applied Sciences, vol. 11, pp. 62-68, 2015. 
[30] H. Saleh, A. Abou El-Azm Aly, and S. Abdel-Hady, "Assessment of different methods used to estimate Weibull distribution parameters for wind speed in Zafarana wind farm, Suez Gulf, Egypt," Energy, vol. 44, no. 1, pp. 710-719, 2012.

[31] J. F. Manwell, J. G. McGowan, and A. L. Rogers, Wind Energy Explained: Theory, Design and Application, John Wiley \& Sons, Amherst, Mass, USA, 2002.

[32] M. Sathyajith, Wind Energy: Fundamentals, Resource Analysis and Economics, Springer, 2006.

[33] A. S. Ahmed, "Potential wind power generation in South Egypt," Renewable and Sustainable Energy Reviews, vol. 16, no. 3, pp. 1528-1536, 2012. 

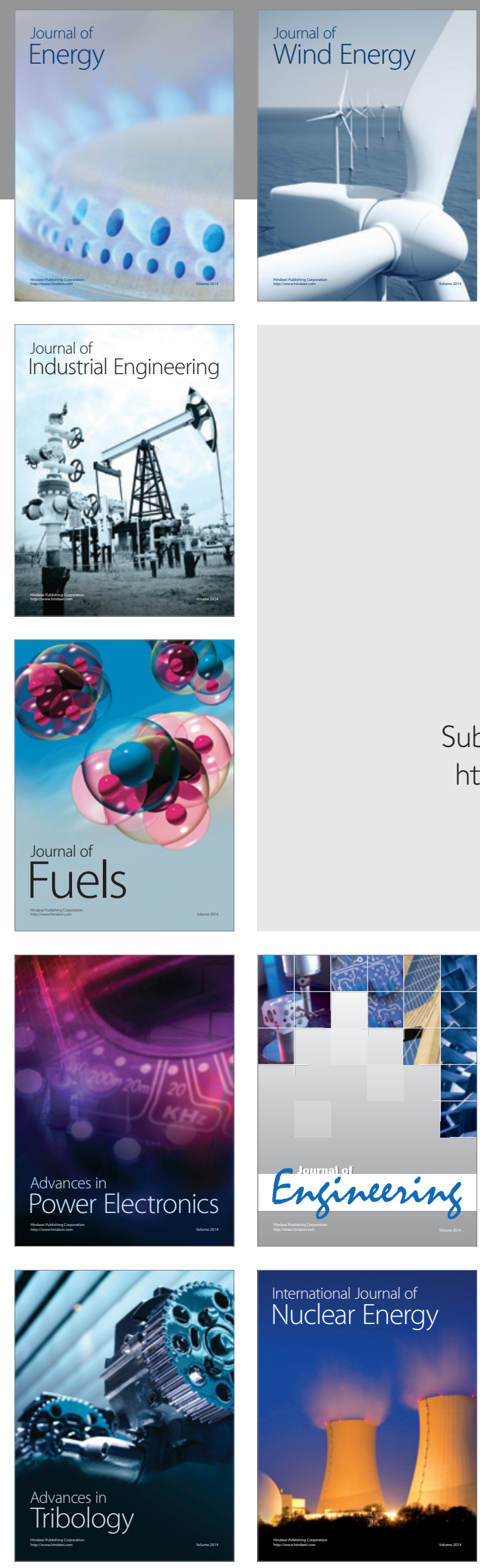

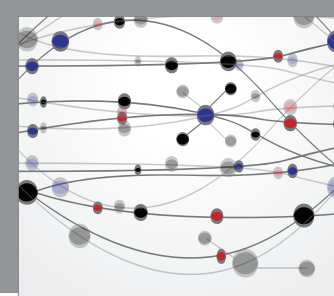

The Scientific World Journal
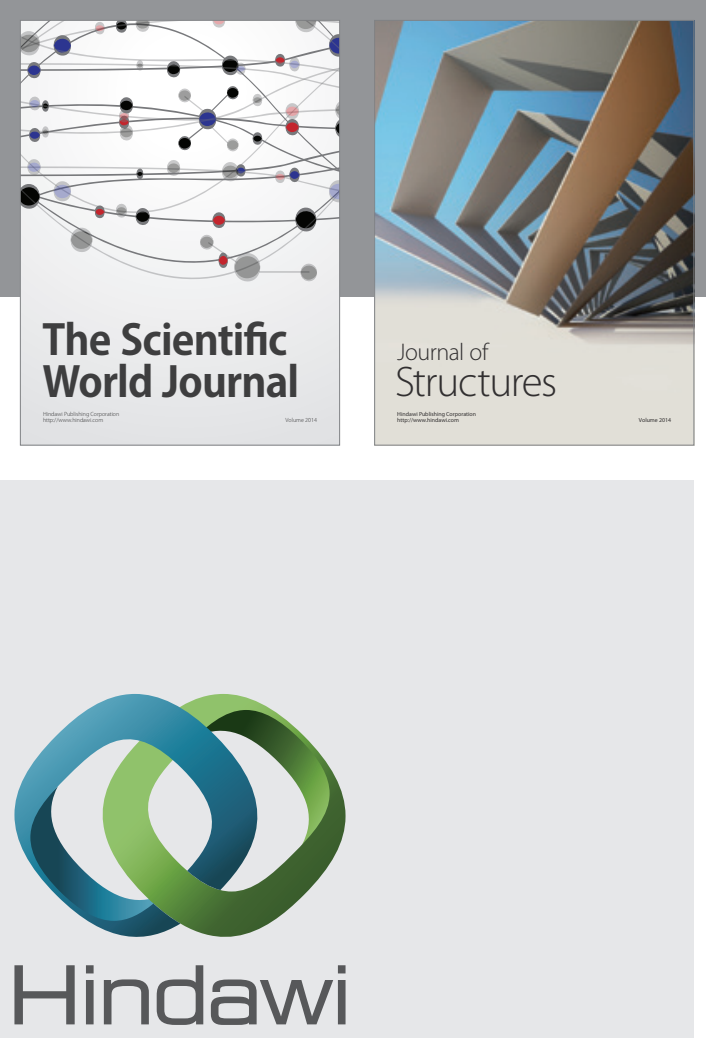

Submit your manuscripts at

https://www.hindawi.com
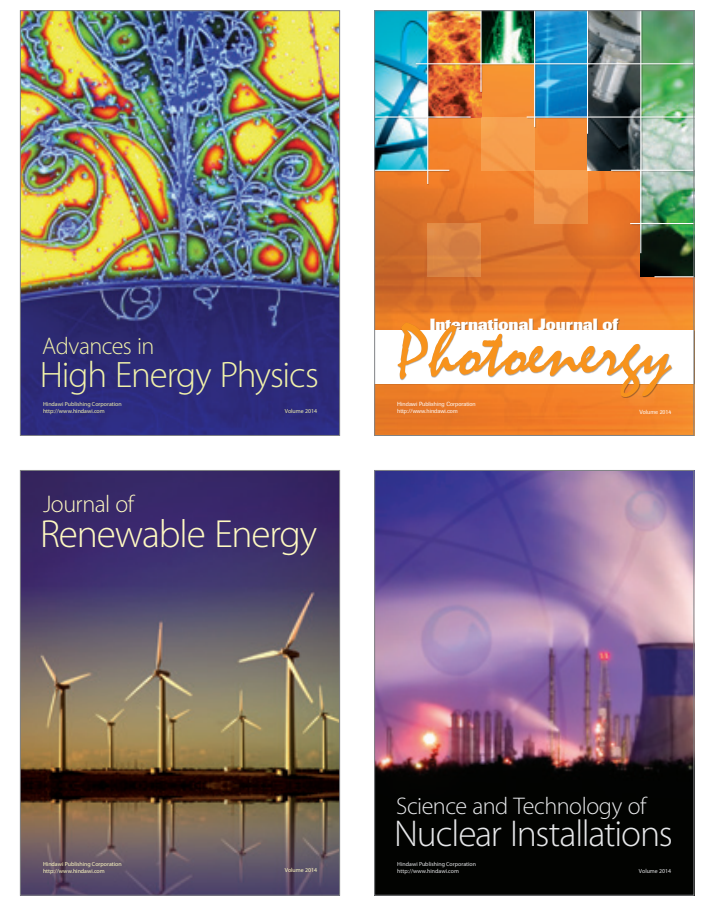
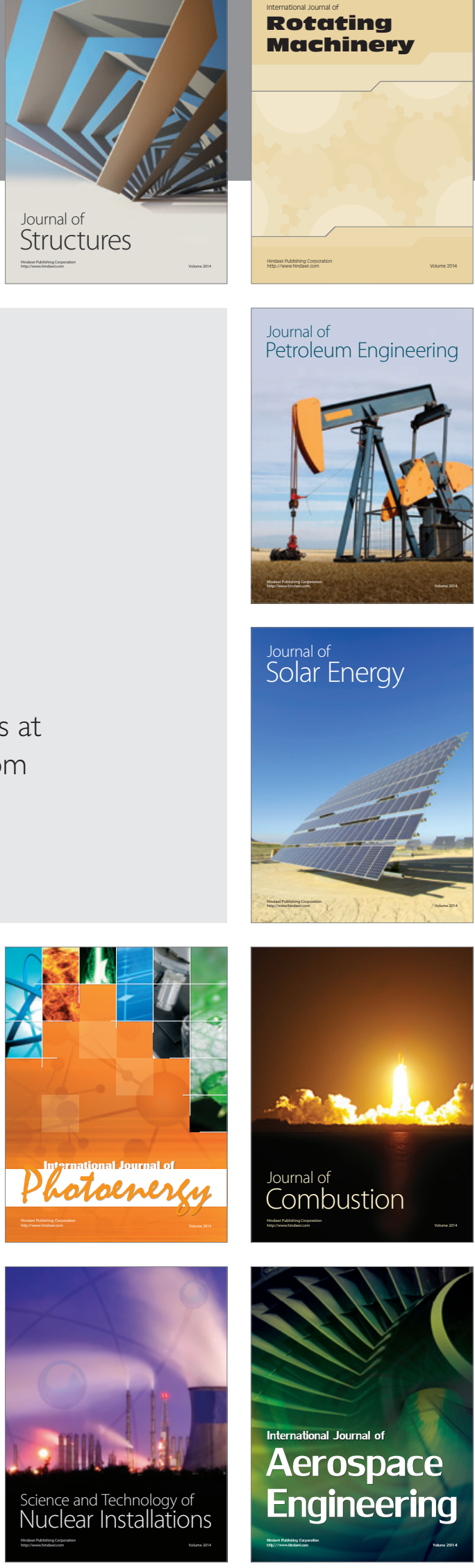